\title{
Erratum to: Physical-chemical explanation of fire-fighting efficiency of FHF (fast-hardening foam) based on structured silica particles
}

\author{
Denis S. Kuprin ${ }^{1}$
}

Published online: 21 April 2017

(C) Springer Science+Business Media New York 2017

\section{Erratum to: J Sol-Gel Sci Technol (2017) 81:36-41 DOI 10.1007/s10971-016-4285-8}

Figures 2, 3, and 8 of the original version of this article are reprinted with permission from Vinogradov AV, Kuprin DS, Abduragimov IM, Kuprin GN, Serebriyakov E, Vino- gradov VV (2015) Silica foams for fire prevention and firefighting. ACS Appl Mater Interfaces 22 October 2015. Copyright 2015 American Chemical Society.

Unfortunately, the reprint permission was not explicitly displayed in the article. This has been corrected with this erratum.
Fig. 2 Chemical mechanism for the formation of FHF (reprinted with permission from

Vinogradov AV, Kuprin DS, Abduragimov IM, Kuprin GN Serebriyakov E, Vinogradov VV (2015) Silica foams for fire prevention and firefighting. ACS Appl Mater Interfaces 22 October 2015. Copyright 2015

American Chemical Society)

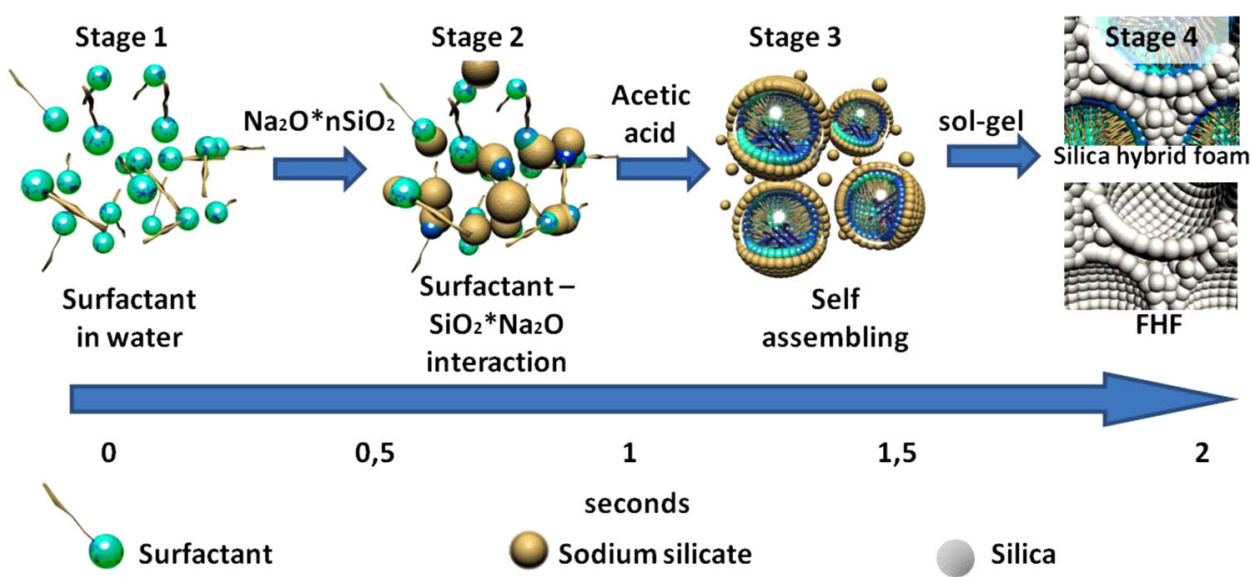

The online version of the original article can be found at doi:10.1007/ s10971-016-4285-8.

\footnotetext{
Denis S. Kuprin

dskuprin@mail.ru

1 LLC "RPA "SOPOT", St. Petersburg, Russia
} 

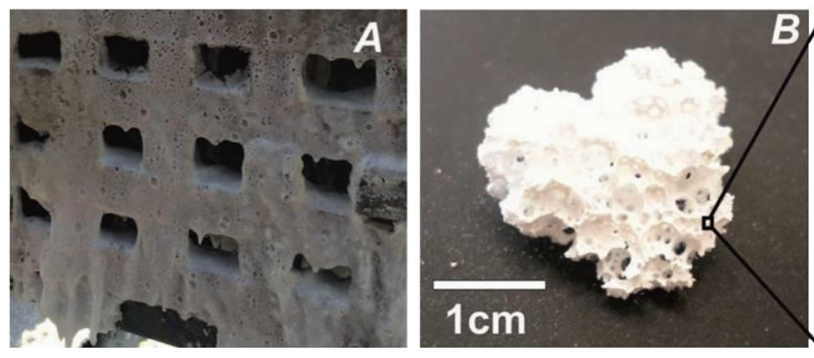

Fig. 3 Photographs $(\mathbf{a}, \mathbf{b})$ and SEM images $(\mathbf{c}, \mathbf{d})$ of FHF (reprinted with permission from Vinogradov AV, Kuprin DS, Abduragimov IM, Kuprin GN, Serebriyakov E, Vinogradov VV (2015) Silica foams for

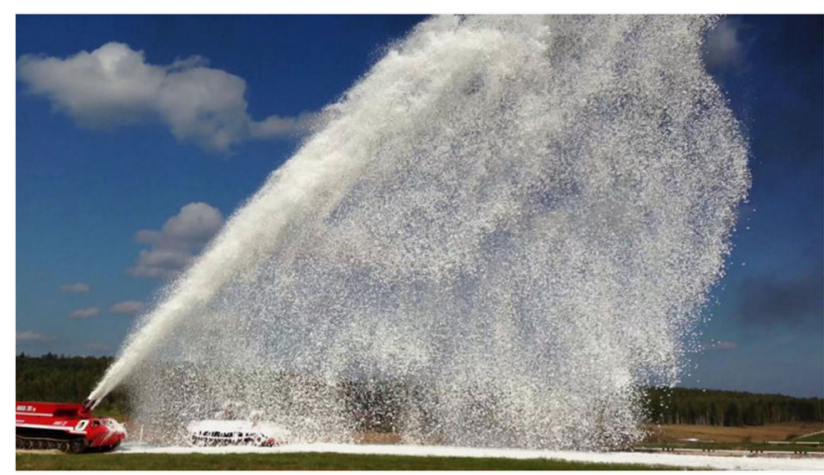

Fig. 8 FHF delivery by fire-fighting tracked vehicle "Yamal-201" (reprinted with permission from Vinogradov AV, Kuprin DS, Abduragimov IM, Kuprin GN, Serebriyakov E, Vinogradov VV (2015) Silica foams for fire prevention and firefighting. ACS Appl Mater Interfaces 22 October 2015. Copyright 2015 American Chemical Society)
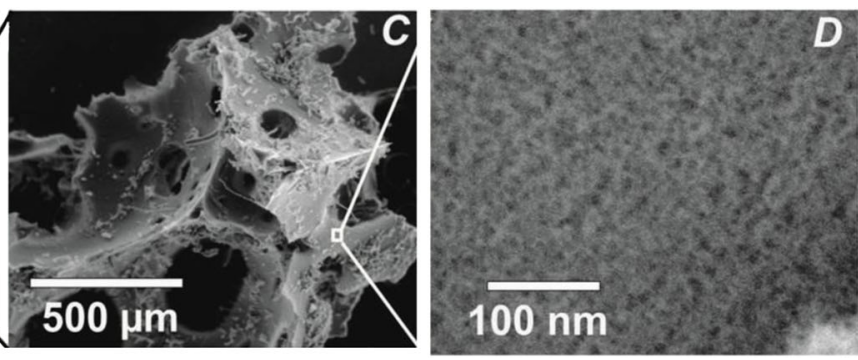

fire prevention and firefighting. ACS Appl Mater Interfaces 22 October 2015. Copyright 2015 American Chemical Society) 